\title{
Weaner sheep grazing dry summer pastures increased wool growth, liveweight and faecal dry matter output in response to rumen protected methionine supplements
}

\author{
G Mata, DG Masters, DJ Buscall, N Chamberlain, T Porter \\ CSIRO Division of Animal Production, Private Bag, PO, Wembley WA 6014, Australia
}

The ability of young growing sheep to buffer against seasonal fluctuations in nutrient availability in Mediterranean environments is restricted due to limited fat and protein reserves. This restriction leads to larger seasonal changes in wool growth and quality than in mature sheep. Mata et al (1992, Proc Aust Soc Anim Prod, 19, 144) showed that grazing sheep will respond in liveweight and feed intake to rumen protected methionine. We tested the hypothesis that young sheep grazing mature pastures over summer and autumn would respond to rumen protected methionine even at low energy intakes from low quality pastures.

One hundred and twenty weaner wethers with an initial liveweight of $32.7 \mathrm{~kg}( \pm 0.3 \mathrm{sem})$ were allocated to two groups : plus (+) or minus (-) methionine. Lactet (Nippon Soda, Japan), a methionine formulation protected from degradation in the rumen was used to provide the methionine. The + group received $3 \mathrm{~g}$ methionine per day fed three times per week using crushed lupins as a carrier. The - group received the crushed lupins only. The supplements were offered until June (189 days), the sheep were then managed as a single mob until shearing. Wool growth, liveweight (LW) and faecal dry matter output (FDM) were monitored at monthly intervals. FDM is an indicator of the pasture intake. Data were analysed by ANOVA (repeated measures or one-way).

Wool growth was significantly increased by Lactet $(+=3.49 \pm 0.1 \mathrm{~kg} ;-=3.03 \pm 0.1 \mathrm{~kg}$, $P<0.001$ ). Staple strength (SS) was not significantly increased $(P=0.09)$ despite a $12.4 \%$ increase $(+=32.9 \pm 1.4,-=29.3 \pm 1.7$ $\mathrm{N} / \mathrm{Ktex}$ ). Wool from the + group would be classed as sound, while that of the - group as part tender and likely to suffer a price penalty. Lactet significantly increased LW during the treatment period $(P<0.001)$ and the difference remained until shearing $(P<0.001)$. $A$ significant difference between groups was not evident until March. By this stage, both the quality and quantity of feed remaining would be limiting. Earlier decline in LW are normally expected, but in 1994 there were no summer rains to reduce the quality of feed during summer and autumn. Under these conditions, an energy deficit was not evident until midautumn and the sheep were able to respond to Lactet through an increase in feed intake and probably an increase in the efficiency of use of absorbed nutrients. The benefits of Lactet supplementation persisted for at least two to three months after cessation of supplements for both wool and LW. Lactet provided an effective way of delivering methionine to young growing sheep grazing dry pastures. This work was supported by IWS and the Nippon Soda Co Ltd, Japan.

\begin{tabular}{lcccccccccc} 
Month & Dec & Jan & Feb & Mar & Apr & May & Jun & Sep & $\mathrm{P}<$ \\
LW $+(\mathrm{kg})$ & -32.8 & 35.4 & 37.0 & 38.3 & 41.4 & 40.2 & 37.4 & 48.4 & 0.001 \\
$\quad(\mathrm{se})$ & 0.41 & 0.47 & 0.49 & 0.46 & 0.51 & 0.52 & 0.46 & 0.61 & \\
$\mathrm{LW}-(\mathrm{kg})$ & 32.7 & 35.4 & 36.4 & 36.4 & 37.9 & 38.1 & 33.7 & 46.6 & \\
$\quad(\mathrm{se})$ & 0.44 & 0.45 & 0.42 & 0.43 & 0.45 & 0.48 & 0.45 & 0.47 & \\
+ FDM (g/d) & 262 & 324 & 386 & 403 & 364 & 382 & - & 302 & 0.023 \\
$\quad(\mathrm{se})$ & 27 & 19 & 19 & 21 & 22 & 21 & & 12 & \\
- FDM (g/d) & 229 & 280 & 342 & 365 & 351 & 350 & - & 206 & \\
$\quad(\mathrm{se})$ & 10 & 14 & 16 & 14 & 17 & 8 & & 17 & \\
\hline
\end{tabular}

